\title{
POTENTION OF ACTIVE CHARCOAL FROM Musa paradisiaca AND Manihot utilissima SHELL IN DEGRADING RIVER CONTAMINATION
}

\author{
Nurlailah, Anny Thuraidah, Yayuk Kustiningsih \\ Department of Medical Laboratory Technology Poltekkes Kemenkes Banjarmasin \\ Mistar Cokrokusumo Street 4a Banjarbaru Indonesia. \\ e-mail: nurlailah874@gmail.com
}

\begin{abstract}
River water is one of type water surface which is a lot of finding in South Kalimantan. Generally, this water used by the citizen for cooking and bathing. But along with era growth, this river becomes as disposal of various industrial waste. The contamination of heavy metal like $\mathrm{Fe}, \mathrm{Mn}, \mathrm{Pb}, \mathrm{Cd}$, and turbidity enhance progressively and degrade the water quality. Some natural substance which can be used to improve river water quality is active charcoal from Musa paradisiaca and Manihot utilissima shell which is easy to get. Target research is determined to find optimum dose of active charcoal from Musa paradisiaca and Manihot utilissima shell that capable to degrade heavy metal contamination and turbidity in water river. It used experimentally with pretest and post-test with control group design. A result of research showed the optimum dose of active charcoal Musa paradisiaca shell was 15 gram, it could absorb $\mathrm{Pb} 28,8 \%$ and $\mathrm{Mn} 24,6 \%$, but 10 gram can degrade turbidity until 83,8 $\%$, while the optimum dose of Manihot utilissima shell to $25,4 \% \mathrm{~Pb}$ and degraded $77,5 \%$ of turbidity was 15 gram. Statistical test result with Kruskal Wallis got the p-value less than 0,05 it meant there was a difference between the treatment of active charcoal from Musa paradisiaca and Manihot utilissima shell in degrading the contamination. A conclusion is those active charcoal having a potential to enhance the water river quality. Suggested to use another activator to the potential like stirring, time of contact and the different mass.
\end{abstract}

Keywords: active charcoal, Musa paradisiaca shell, Manihot utilissima shell, contamination

\section{INTRODUCTION}

Fulfillment of clean water needs has become the common problem and can not solve in most parts of Indonesia in general, including in Kalimantan region. The island of Borneo, especially South Kalimantan, which is famous for its nickname of a thousand rivers, is also experiencing the same problem. The difficulty of citizens in the fulfillment of clean water is inseparable from the increase of human activity with the technological advances in various aspects of life.

One source of water that can be utilized by residents who live in the vicinity of river banks is river water that generally comes from peat soil. Peat river water is under standards for use for bathing, washing and especially for drinking and is further exacerbated by the entry of various types of waste, especially metal waste due to increased human activity aspects of life.
The difficulty of fulfilling the need for clean water will have an impact on the health of the community, namely the outbreak of various diseases such as diarrhea, topical diseases to cancer so it takes a simple water treatment effort that is easy to do by the community, cheap and environmentally friendly. The characteristic of polluted river water is marked by a murky color, causing dermatitis and uncomfortable aroma.

Carbon or activated charcoal is one of the alternatives that can be used to improve the quality of polluted river water. Activated charcoal is an adsorbent material that can absorb various contaminants such as heavy metals, lowering COD, BOD, turbidity and can eliminate the color and aroma that interfere. According to Jusmanizah(2011), activated charcoal is a type of carbon that can be enlarged surface area by way of activated first. 
Some natural ingredients that have potential to make activated charcoal are genjer, coconut shell, corn cob, rice husk, Manihot utilissima shell, Musa paradisiacal shell, water hyacinth and others. Shell of Musa paradisiaca and Manihot utilissima is a natural waste that is environmentally friendly and available around us, including in the area of South Kali- times.

mantan. According to Castro et al. (2011) Musa paradisiacal shell that has been dried and then mixed with water, could clean water from metal cause metal attached to the charcoal of Musa paradisiaca. Adinata research result, M.R (2003), that the shell of Musa paradisiaca contains high enough carbon and after activated with $2 \mathrm{~N}$ sulfuric acid having carbonization equal to $96,56 \%$. While the results of Rajagukguk (2011) study revealed that Manihotut ilissima shell-activated carbon was able to decrease BOD waste from 1013,2 mg / I to 150 $\mathrm{mg} / 1$ and TSS from $1722 \mathrm{mg} / \mathrm{I}$ to $56,4 \mathrm{mg} / \mathrm{I}$ with carbon weight active used as much as 1 gram in $200 \mathrm{ml}$ of tofu waste. Jusmanizah (2011), Manihot utilissima shell contains $59.31 \%$ carbon that can be used as activated carbon to absorb various chemical compounds in water or liquid waste. Manihot utilissima shell charcoal that has activated with $\mathrm{KOH}$ (Yuningsih et al., 2016) or $\mathrm{HCl}$ (Supiati at. al., 2013) can improve its adsorption ability.

The shell waste of Musa paradisiaca and Manihot utilissima has not been fully utilized by the local people so this waste is only a pile of waste that is not useful. It is necessary to further explore the utilization of these wastes as an alternative in reducing the level of river water pollution present in Kalimantan, especially in South Kalimantan by making a formula of active concentration of Musa paradisiacal shell and Manihot utilissima shell which is optimal in reducing heavy metal pollution levels, turbidity, $\mathrm{pH}$, color and odor in water. The purpose was to determine the optimum weight of Musa paradisiaca shell active charcoal in reducing heavy metals and turbidity in river water. Determine the optimum weight of Manihot utilissima shell active charcoal in reducing heavy metals and turbidity in river water.

\section{MATERIALS AND METHODS}

The type of this research is the experiment with research design using pretest and post-test with a control group. This study has measured heavy metal, turbidity, $\mathrm{pH}$, and river water odor levels before being treated and after being treated with a shell of Musa paradisiaca and Manihot utilissima with the dose of $5 \mathrm{gr}, 10 \mathrm{gr}$ and $15 \mathrm{gr}$ in $250 \mathrm{ml}$ water river. Stirring with contact time between water and carbon for 2 hours, repetition has been done 3

The sample has been burned to charcoal at a temperature of $500^{\circ} \mathrm{C}$, sieved with a mesh size of 100 mesh. Activation has been performed using $\mathrm{HCl} 1 \mathrm{~N}$. Neutral carbon has been dried in an oven temperature of $110 \mathrm{oC}$ for 3-4 hours. Water and absorption test against iodine have tested.

The Activated Carbon of Musa Paradisiaca and Manihot utilissima were performed in 3 groups (5gr, 10gr, 15gr) each with 3 repetitions plus control group. The treatment has used $250 \mathrm{ml}$ of river water containing heavy metals $(\mathrm{Pb}, \mathrm{Cd}$, and $\mathrm{Fe})$ in contact with activated charcoal for 2 hours. The filtered water has checked for heavy metals parameters (Fe, Mn, $\mathrm{Cd}$ and $\mathrm{Pb}$ ) using the Automatic Absorption Spectrophotometer (AAS) (Shimazu AA-7000), turbidimeter using turbidimetry Lovibond Water Testing, $\mathrm{pH}$ using $\mathrm{pH}$ meter Horiba D-54 and odor done by directly kissing the aroma of water manually.

\section{RESULTS AND DISCUSSION}

The examination material used to test the absorption ability of the shell Musa paradisiaca and Manihot utilissima is river water in Pekauman Martapura with water characteristic as follows:

Table.1 Result of organoleptic examination and $\mathrm{pH}$

\begin{tabular}{lcc}
\hline & \multicolumn{2}{c}{ Contact with Musa paradisiaca and Manihot } \\
Parameter & Before & Aftilissima shell \\
\hline $\mathrm{pH}$ & Base $(\mathrm{pH}: 7,0-7,1)$ & Acid $(\mathrm{pH}: 1,4-3,5)$ \\
Smell & Fishy & Normal \\
Color & Cloudy & Clearer \\
\hline
\end{tabular}

Table 2. Water and Ash Content of the charcoal

Analysis results

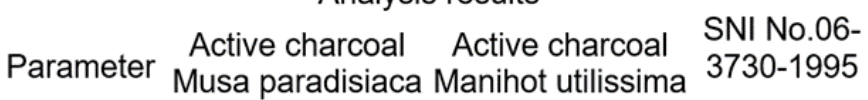
shell shell

$\begin{array}{cccc} & \text { shell } & \text { shell } & \\ \text { Water } & 12,4 \% & 25,3 \% & \text { Max. } 15 \%\end{array}$

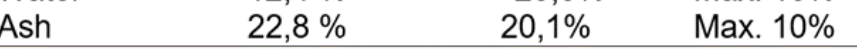


Table 3. Average metal content and turbidity of river water samples after treatment with Active charcoal Musa paradisiaca shell

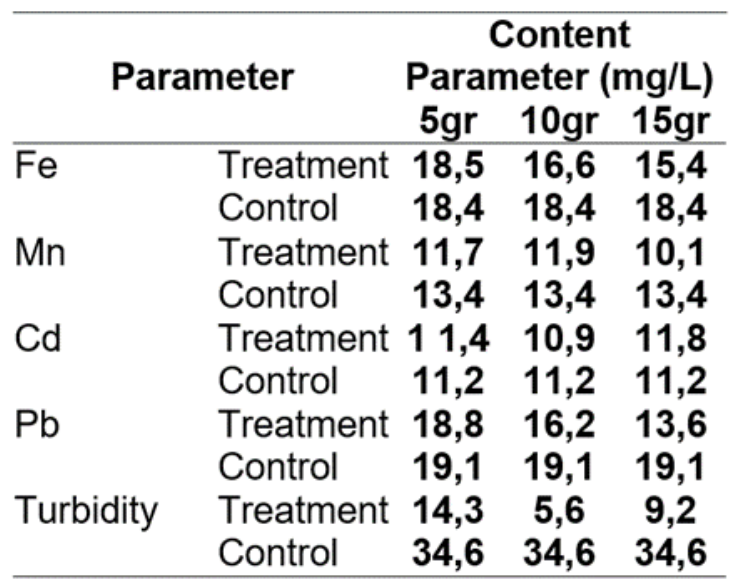

Table 4. Average metal content and turbidity of river water samples after treatment with Active charcoal Manihot utilissima Shell

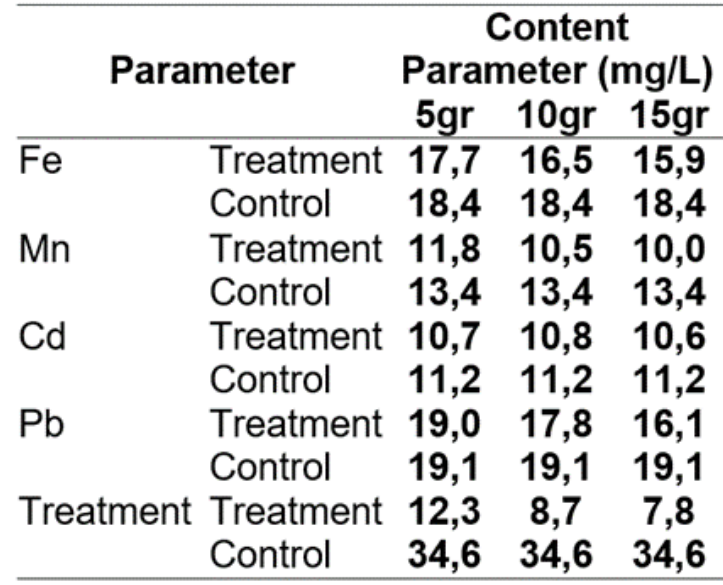

Table 5. Average of Percentage decrease in metal content and turbidity of river water after contact with Musa paradisiaca and Manihot utilissima Shell

\begin{tabular}{lcccccc}
\hline \multirow{2}{*}{ Parameter } & \multicolumn{6}{c}{ Average decrease content (\%) } \\
& \multicolumn{2}{c}{$\mathbf{5 ~ g r}$} & \multicolumn{2}{c}{ 10 gr } & \multicolumn{2}{c}{$\mathbf{1 5} \mathbf{~ g r}$} \\
\cline { 2 - 7 } & Musa & Manihot & Musa & Manihot & Musa & Manihot \\
\hline $\mathrm{Fe}$ & $-0,54$ & 3,8 & 9,8 & 10,3 & 16,3 & 13,6 \\
$\mathrm{Mn}$ & 12,7 & 11,9 & 11,2 & 21,6 & 24,6 & 25,4 \\
$\mathrm{Cd}$ & $-1,8$ & 4,5 & 2,7 & 3,6 & $-5,4$ & 5,4 \\
$\mathrm{~Pb}$ & 1,6 & 0,5 & 15,2 & 6,0 & 28,8 & 15,7 \\
Turbidity & 58,6 & 64,0 & 83,8 & 74,8 & 73,4 & 77,5 \\
\hline
\end{tabular}

Table 5 shows that turbidity parameter is the highest decreases, in $10 \mathrm{gr}$ of charcoal Musa paradisiaca shell $(83,8 \%)$ and $15 \mathrm{gr}$ shell of Manihot utilissima (77,5\%). While Fe, Mn, and $\mathrm{Pb}$ having the highest decreases in $15 \mathrm{~g}$ Manihot $\mathrm{sp}$ and Musa sp. Cd decreased by Manihot sp. From the normality test results obtained data that not normally distributed because of the significance of the results = $0,000<0.05$. The data distributed followed by Kruskal Wallis test and got significance value < 0,05 meaning that there is the significant difference in treatment with a shell of Musa paradisiaca and Manihot utilissima.

Furthermore, to know the difference between 2 groups done by Mann-Whitney $U$ different test, ie, in treatment group with active charcoal Musa paradisiaca shell and active charcoal Manihot utilissima shell at all doses $(5,10$ and $15 \mathrm{gr})$ showed significant difference of $\mathrm{Fe}, \mathrm{Mn}, \mathrm{Cd}, \mathrm{Pb}$, and turbidity to group without treatment but on treatment with active charcoal Musa paradisiaca shell between $5 \mathrm{gr}$ and $10 \mathrm{gr}$ for $\mathrm{Mn}$ metal content no significant difference. While in the treatment group with active charcoal Manihot utilissima shell only between $5 \mathrm{gr}$ and $10 \mathrm{gr}, 5 \mathrm{gr}$ and $15 \mathrm{gr}, 10 \mathrm{gr}$ and $15 \mathrm{gr}$ did not show any significant difference in Cd content. (table 4)

Based on the results of the study (table 5 ) it is known that both Musa paradisiaca active charcoal and Manihot utilissima shell active charcoal have similar ability in reducing heavy metal contamination and turbidity in water even though the decrease is not optimum yet. The metal content and turbidity in water due to absorption ability of Musa paradisiaca leather and Manihot utilissima leather.

Absorption ability of Musa paradisiaca and Manihot utilissima shell caused by their contains high enough carbon element. To optimize the absorption capacity of carbon in the of Musa paradisiaca and Manihot utilissima, several steps must be taken, among others, carbonization or carbon formation with characteristics of a very small pore space and then activation process with the aim of increasing or increasing the pore diameter of carbon with oven at temperature in order to eliminate the water content that may still exist in the. The ability of active charcoal absorption is also affected by the speed of stirring, contact time and warming. According to Syauqiah I., Amalia M., Kartini H.A. (2011) the of contact time and the heating of the shell used decrease water content and increases the adsorption. 
Based on table 3 it can be seen that the contacted with active charcoal Musa dosage of active charcoal sample of Musa paradisiaca shell and active charcoal Manihot paradisiaca and Manihot utilissima shell which utilissima shell with various dose variations has the highest absorption ability of metal is at showed better turbidity absorption ability $15 \mathrm{gr}$ active charcoal Musa paradisiaca shell compared to the absorption ability of heavy $(28.8 \%)$, with $\mathrm{Pb} 28.8 \%$, followed by Mn metal metals. The absorption of turbidity in both of $24.6 \%$. While for active charcoal Manihot active charcoal Musa paradisiaca shell and utilissima shell, the highest absorption of active charcoal Manihot utilissima shell occurs at $15 \mathrm{gr}$ doses of active charcoal increased with increasing dosage and Manihot utilissima shell (25.4\%) and $10 \mathrm{gr}$ decreased after $15 \mathrm{gr}$ of active charcoal Musa $(21.6 \%)$. So the higher dose of charcoal given paradisiaca shell to $73.4 \%$ from $83.4 \%(10 \mathrm{gr})$. the more absorbs the metal contained in water.

The negative value on the results active charcoal Musa paradisiaca shell and active charcoal Manihot utilissima shell based showed that the Musa paradisiaca shell on doses can caused by differences in the charcoal that has added to the treatment gives amount of activated carbon and the water effect of adding heavy metals to the examined content contained in the two charcoal. Based water. That is, the treatment with $5 \mathrm{gr}$ active on the result of water level inspection on active charcoal Musa paradisiaca shell gives a higher charcoal Musa paradisiaca shell and active yield of Fe content of $18.5 \mathrm{ppm}$ compared with charcoal Manihot utilissima shell, the water no Ogr active charcoal Musa paradisiaca shell) content of active charcoal Musa paradisiaca that is $18,4 \mathrm{ppm}$ with percentage value shell is $12,4 \%$, and active charcoal Manihot decreased $-0,54 \%$. Similarly, at $5 \mathrm{gr}$ of active utilissima shell is $25,3 \%$. With an active charcoal Musa paradisiaca shell give a result charcoal Musa paradisiaca shell water content of the increase of the metal content of $\mathrm{Cd}$ from of $12.4 \%$ allows the active charcoal Musa $11,2 \mathrm{ppm}$ to $11,4 \mathrm{ppm}$ with the value of paradisiaca shell to absorb more suspended decrease percentage $-1,8 \%$.

materials, colloids and water-smoother

The variation in the ability of shell particles than the active charcoal Manihot charcoal of Musa paradisiaca and Manihot utilissima shell in the same dose (Khopkar, utilissima which differs in absorbing the 2003).

pollutant metal in this research can cause by

the heating temperature, type, and concentration of activator materials used and the polarity of the charcoal. According Jamilatun, Setiawan, 2014 temperature is one factor that can affect the ability of active charcoal absorption. In this study used heater furnace for carbonization of charcoal with temperature $400 \mathrm{C}$ for 2 hours. Similar studies using $700 \circ \mathrm{C}$ for shell carbonization Manihot utilissima has a greater ability to absorb Fe REFERENCES

metals in water (Ar Yani et al., 2017). The Adinata, M. R. (2003). Pemanfaatan Limbah activator used in this study is $0.1 \mathrm{~N} \mathrm{HCl}$ which may have been contaminated by heavy metals thereby reducing the ability of active charcoal Musa paradisiaca and Manihot utilissima shell to absorb contained in water. Also, the use of $\mathrm{HCl}$ as an activator in this study caused the $\mathrm{pH}$ of the treated water become acidic, thus affecting the process of metal absorption on the shell of Musa paradisiaca and Manihot utilissima.

The ability to decrease turbidity is one of the parameters tested in this study. The result of turbidity measurements after the river water Kulit Musa paradisiaca sebagai Karbon Aktif. Universitas Pembangunan Nasional Vetran Surabaya.

Ariyani, et al. (2017). Pemanfaatan Kulit Manihot utilissima sebagai Bahan Baku Arang Aktif dengan Variasi Konsentrasi $\mathrm{NaOH}$ dan Suhu. Konversi, 6(1).

Castro et al. (2011). Bananapeel applied to thesolid phase extraction of copper and lead from river water preconcentration of metal ions with a fruit waste. Industrial and Engineering Chemistry Research.

Copyright (C) 2018, MLTJ, ISSN 2461-0879 
Jamilatun, S., \& Setyawan, M. (2014). Pembuatan Arang Aktif dari Tempurung Kelapa dan Aplikasinya untuk Penjernihan Asap Cair. Spektrum Industri, 12(1).

Juzmanisah. (2011). Efektivitas Karbon Aktif Kulit Manihot utilissima dalam Menurunkan Kadar Besi (Fe) dan Mangan (Mn) Air Sumur Gali di Desa Amplas Kecamatan Percut Sei Tuan, Kabupaten Deli Serdang, tahun 2011. Fakultas Kesehatan Masyarakat, USU.

Khopkar, S. M. (2003). Kimia Analitis. Jakarta: Ul-Press.

Rajagukguk, F., H. (2011). Efektifitas Karbon Aktif Kulit Manihot utilissima untuk Menurunkan Kadar Biologycal Oksygen Demand (BOD) dan Total Suspended Solid (TSS) Air Limbah Pabrik Tepung Tapioka.

Supiati, Yadi, M., \& Chadijah, S. (2013). pengaruh konsentrasi activator asam chloride $(\mathrm{HCl})$ terhadap kapasitas adsorpsi arang aktif kulit durian (Durio zibethinus) pada zat warna methanol yellow. Al Kimia, 53-63.

Syauqiah I, Amalia M, Kartina H. . (2011). Analisis Variasi Waktu dan Kecepatan Pengaduk pada Proses Adsorpsi Limbah Logam Berat dengan Arang Aktif. Jurnal Info Teknik, 12(1).

Yuningsih, L. M., Mulyadi, D., \& Kurnia, A. J. (2016). Pengaruh Aktivasi Arang Aktif dari Tongkol Jagung dan Tempurung Kelapa Terhadap Luas Permukaan dan Daya Jerap lodin. Jurnal Kimia Valensi, 2(1), 3034. 